\title{
Analisis Permintaan Kuantitas dan Kualitas Beras di DKI Jakarta
}

\author{
Nila Windiyarti ${ }^{1 *}$, Sri Hartoyo ${ }^{2}$, Tanti Novianti ${ }^{2}$ \\ ${ }^{1}$ Badan Pusat Statistik, Provinsi DKI Jakarta \\ ${ }^{2}$ Departemen Ilmu Ekonomi \\ Fakultas Ekonomi dan Kebijakan Pembangunan, Institut Pertanian Bogor \\ Korespondensi: artinila@bps.go.id
}

[diterima: Agustus 2018-revisi: September 2018-diterbitkan daring: Desember 2018]

\begin{abstract}
ABSTRAK
Beras merupakan salah satu makanan pokok yang mendominasi pemenuhan kebutuhan karbohidrat penduduk. Meningkatnya tingkat pendapatan penduduk menyebabkan preferensi terhadap beras yang dikonsumsi berubah. DKI Jakarta adalah provinsi dengan tingkat pendapatan yang terbesar di Indonesia. Penelitian ini bertujuan untuk menganalisis faktor-faktor yang memengaruhi permintaan beras dan melihat perubahan respon permintaan kuantitas dan kualitas beras terhadap perubahan pendapatan dan harga di Provinsi DKI Jakarta. Data yang digunakan berasal dari SUSENAS DKI Jakarta periode Maret 2017. Jenis data yang digunakan merupakan data cross section dengan unit sampel 5.200 rumah tangga. Metode penelitian yang digunakan adalah regresi linier berganda dalam bentuk dua persamaan tunggal semilog. Hasil penelitian menunjukkan bahwa pendapatan perkapita, harga beras dan jumlah anggota rumah tangga secara positif memengaruhi permintaan beras di DKI Jakarta. Elastisitas pengeluaran dan kuantitas beras menunjukkan nilai yang positif. Hal ini menunjukkan kenaikan pendapatan akan memengaruhi permintaan beras dari sisi kuantitas dan kualitas beras. Sementara elastisitas harga silang menunjukkan arah yang beragam untuk terigu dan daging ayam.
\end{abstract}

Kata kunci: elastisitas, permintaan beras, semi-logartima model

\begin{abstract}
Rice is one of the staple foods that dominates the fulfillment of carbohydrate needs of the population. The increase in population income causes the change in rice consumption preferences. DKI Jakarta is the province with the highest income level in Indonesia. This research aims to analyze the factors affecting the demand for rice in DKI Jakarta Province and analyze the change in demand for rice quantity and quality due to changes in income and price in DKI Jakarta. The data used in this study is from SUSENAS (National Socio-Economic Survey) for DKI Jakarta in March 2017. The data is cross section with sampling unit of 5200 households. The method used is multiple linear regression in the form of two singular semi-log equations. The results show that per capita income, rice price and the number of household members positively influences the demand for rice in DKI Jakarta. Expenditure and quantiiy elasticity of rice is positive. This means that the increase in income is related to increase in demand for rice in terms of quantity and quality. Meanwhile, the value of cross price elasticity shows varied sign.
\end{abstract}

Keywords: demand for rice, elasticity, semi-logarithmic

JEL classification: Q11, D10, C21 


\section{PENDAHULUAN}

Pangan merupakan zat yang dibutuhkan manusia dalam menunjang aktivitasnya seharihari. Pemenuhan akan kebutuhan pangan merupakan hak asasi manusia yang dijamin dalam Undang-Undang Dasar Tahun 1945 sebagai komponen dasar dalam mewujudkan sumber daya manusia yang berkualitas. Pemenuhan kecukupan pangan perseorangan merupakan esensi dari UU No.18 Tahun 2012 pasal 4 mengenai ketahanan pangan yang dicerminkan oleh tersedianya pangan yang cukup, baik jumlah maupun mutunya, aman, beragam, bergizi, merata, dan terjangkau harganya serta tidak bertentangan dengan agama, keyakinan, dan budaya masyarakat, untuk dapat hidup sehat, aktif, dan produktif secara berkelanjutan (Kemendag 2013).

DKI Jakarta merupakan ibu kota provinsi yang tingkat pendapatan perkapitanya paling tinggi secara nasional. Jika diamati, rata-rata pendapatan perkapita DKI selalu berada jauh di atas rata-rata nasional dan nilainya terus meningkat. Peningkatan pendapatan berdampak pada perubahan preferensi penduduk terhadap barang. Dengan pendapatan yang relatif tinggi, penduduk akan lebih leluasa dalam membelanjakan uangnya sesuai dengan seleranya.

Jenis padi di Indonesia ditinjau dari warna berasnya cukup beragam antara lain beras putih, beras merah, dan beras hitam. Adapun kualitasnya, bisa dibedakan menurut padi hibrida, unggul, dan lokal. Dewasa ini, seiring perkembangan teknologi yang semakin maju, maka dikenal pula beras organik. Menurut Agustina (2012), pemilihan beras merupakan ungkapan selera pribadi konsumen, ditentukan oleh faktor subjektif dan dipengaruhi oleh lokasi, suku bangsa atau etnis, lingkungan, pendidikan, status sosial ekonomi, jenis pekerjaan, dan tingkat pendapatan.

Pada tahun 2017, rata-rata penduduk DKI Jakarta dengan tingkat pendapatan 300 ribu hingga 499 ribu rupiah mengeluarkan sebesar $\mathrm{Rp}$ 9983 untuk mengonsumsi beras dalam seminggu. Sementara penduduk dengan tingkat pendapatan per kapita di atas 1.5 juta rupiah mengeluarkan sebesar $\quad \mathrm{Rp} \quad 12 \quad 268$ untuk mengonsumsi beras dalam seminggu. Fenomena ini menunjukkan semakin tinggi golongan pendapatan maka pengeluaran untuk beras semakin besar. Besarnya pengeluaran untuk beras pada kelompok rumah tangga dengan pendapatan yang semakin tinggi mungkin saja dipengaruhi oleh pemilihan jenis beras yang lebih mahal yang mencerminkan kualitas yang semakin baik. Peningkatan tingkat pendapatan menyebabkan tingkat utilitas penduduk tidak hanya terpenuhi dengan mengonsumsi beras dengan kualitas biasa tetapi penduduk menuntut persyaratan yang lebih yaitu beras dengan kualitas lebih baik dan rasa lebih enak (Erwidodo et al. 1997; Wibowo 2017).

Kualitas makanan dapat didefinisikan dalam keragaman bentuk makanan seperti warna, rasa, dan bentuk sementara proses berhubungan dengan faktor-faktor seperti metode dalam proses pembuatan dan dampak lingkungan yang ditimbulkan akibat proses produksi (Ogundari 2012). Dalam hal ini kualitas beras yang dimaksud meliputi rasa, bentuk, warna, dan sebagainya. Kualitas beras dalam penelitian ini dicerminkan dari tingkat harga. Kualitas beras yang rendah dicerminkan dengan harga yang relatif lebih murah dibandingkan dengan beras kualitas tinggi.

Beberapa penelitian sebelumnya lebih banyak berfokus kepada hubungan antara pendapatan rumah tangga dan konsumsi dalam bentuk elastisitas pendapatan yang hanya menjelaskan perubahan kuantitas relatif terhadap pendapatan dan mengabaikan pentingnya efek kualitas (Fayaz et al. 2014). Rekomendasi kebijakan yang didapatkan tidak dengan menghitung elastisitas permintaan kualitas akan memberikan hasil yang kurang tepat (Yu dan Abler 2009). Penyebabnya adalah naiknya permintaan mungkin tidak menunjukkan adanya peningkatan permintaan dari segi kualitas. Jika hanya dari segi kuantitas maka hanya akan terlihat respon perubahan permintaan beras dari segi kuantitas namun tidak terlihat perubahan pilihan konsumsi yang berkaitan dengan kualitas beras.

Berkaitan dengan permasalahan yang telah diuraikan sebelumnya, maka penelitian tesis ini bertujuan untuk (1) Menganalisis faktor-faktor yang memengaruhi permintaan beras yang dikonsumsi rumah tangga di DKI Jakarta tahun 2017. (2) Menganalisis respon perubahan 
permintaan dari sisi kuantitas dan kualitas beras yang dikonsumsi rumah tangga di DKI Jakarta tahun 2017.

Hipotesis penelitian ini adalah tingkat pendapatan yang semakin tinggi akan menyebabkan elastisitas permintaan kualitas beras semakin rendah dan semakin rendah tingkat pendapatan maka elastisitas permintaan kualitas beras semakin tinggi.

Tingkat sensitivitas penduduk yang berada pada kelompok pendapatan yang tinggi tidak terlalu tinggi terhadap perubahan harga beras dan pendapatan. Sehingga jika terjadi kenaikan harga beras, penduduk pada kelompok ini tidak serta merta menurunkan kualitas beras yang dikonsumsi. Apabila terjadi kenaikan pendapatan, penduduk pada kelompok tinggi tidak langsung mengubah konsumsi berasnya menjadi beras yang lebih baik lagi. Hal ini disebabkan karena penduduk pada kelompok tinggi memang sudah mengkonsumsi beras dengan kualitas yang baik sehingga respon terhadap perubahan harga dan pendapatan tidak begitu besar

\section{TINJAUAN PUSTAKA}

Dornbusch et al. (2004) menyatakan bahwa fungsi konsumsi merupakan hubungan antara konsumsi dan pendapatan. Fungsi permintaan merupakan sebuah representasi yang menyatakan bahwa kuantitas yang diminta tergantung pada harga, pendapatan, dan preferensi (Nicholson 2002).

Kurva engel merupakan fungsi yang menggambarkan bagaimana pengeluaran konsumen terhadap barang atau jasa berhubungan dengan sumber daya yang dimiliki. Engel menemukan bahwa pengeluaran makanan merupakan fungsi dari pendapatan dan ukuran rumah tangga. Rumah tangga dengan jumlah anggota rumah tangga yang besar memiliki anggaran yang besar untuk barang kebutuhan tertentu jika dibandingkan dengan rumah tangga dengan jumlah anggota rumah tangga yang sedikit pada tingkat pendapatan yang sama.

Teori prilaku konsumen menjelaskan bahwa konsumen yang rasional akan memilih konsumsi barang yang dapat memberikan kepuasan yang lebih tinggi (Deaton and Muellbauer 1980). Hal ini menunjukkan bahwa konsumen akan berusaha untuk melakukan pilihan kualitas barang yang dibeli. Pilihan kualitas dengan sendirinya merefleksikan pengaruh harga sebagai respon konsumen terhadap perubahan harga dengan melakukan pertukaran baik dari segi kuantitas maupun kualitas (Deaton 1988).

Harianto (1994) menggunakan bentuk semilogarithmic single equation model untuk melihat respon perubahan harga dan pendapatan terhadap perubahan permintaan kuantitas dan kualitas. Hasil penelitian menunjukkan bahwa elastisitas kualitas harga dan pendapatan memiliki nilai yang positif. Elastisitas kuantitas terkait dengan tingkat pendapatan menunjukkan nilai yang positif. Sementara elastisitas terkait dengan harga silang ada yang bernilai positif dan ada yang bernilai negatif.

Huang dan Gale (2007) menggunakan persamaan double log single equation model untuk menganalisis permintaan makanan dari sisi kuantitas dan kualitas. Hasil penelitian menunjukkan baik elastisitas kuantitas maupun kualitas menunjukkan nilai yang bervariasi, ada yang positif maupun negatif untuk seluruh jenis makanan.

Analisis kuantitas dan kualitas yang dikaitkan dengan tingkat pendapatan dilakukan oleh Ogundari (2012) untuk melihat pola permintaan daging, ayam dan ikan di Nigeria. Persamaan yang digunakan adalah double logarithmic single equation model. Hasil penelitian menunjukkan seluruh nilai elastisitasnya positif dari segi kuantitas maupun kualitas.

Penelitian untuk melihat respon perubahan harga dan pendapatan terhadap permintaan kuantitas dan kualitas buah-buahan di Provinsi Lampung dilakukan oleh Desfaryani (2015) dengan menggunakan bentuk semi-logartihmic single equation model. Hasil penelitian menunjukkan elastisitas harga silang buahbuahan menunjukkan ada yang bernilai positif dan ada yang negatif dari segi kuantitas maupun kualitas. Sementara nilai elastisitas pendapatan bernilai positif untuk seluruh buah yang dianalisis baik dari segi kuantitas maupun kualitas. George dan King dalam Desfaryani (2015) memperkirakan bahwa umumnya elastisitas kualitas sehubungan dengan pendapatan adalah positif. Seseorang pada kelompok pendapatan yang lebih tinggi 
membayar lebih besar dibandingkan seseorang pada kelompok pendapatan rendah untuk jumlah yang sama. Seseorang menghabiskan uangnya untuk membeli sebuah barang pada kuantitas tertentu dengan kualitas tertentu. Jika terdapat dua orang menghabiskan sejumlah uang yang sama untuk membeli sebuah barang yang sejenis dengan jumlah yang berbeda, maka dapat dikatakan bahwa terdapat perbedaan kualitas terhadap barang yang dibeli oleh kedua orang tersebut.

\section{METODE Jenis dan Sumber Data}

Penelitian tentang pola permintaan beras ini akan memberikan kontribusi terhadap penelitian yang spesifik melihat pola permintaan beras yang tidak hanya melihat dari segi permintaan kuantitas beras. Kebaruannya terletak pada efek kualitas yang ingin dilihat dari perubahan harga dan pendapatan penduduk terhadap permintaan beras.

Penelitian menggunakan data sekunder dari hasil Survei Sosial Ekonomi (Susenas) periode Maret tahun 2017. Variabel yang digunakan dalam penelitian ini adalah kuantitas beras yang dikonsumsi rumah tangga dalam sebulan $(\mathrm{kg})$, pengeluaran beras yang dikonsumsi rumah tangga dalam sebulan (Rp), harga beras (Rp), harga terigu $(\mathrm{Rp})$, harga ayam $(\mathrm{Rp})$, total pendapatan rumah tangga yang diproksi dari total pengeluaran rumah tangga (Rp) dan jumlah anggota rumah tangga (jiwa) sebagai karakteristik sosial rumah tangga.

Pemilihan terigu sebagai barang substitusi beras dan daging ayam sebagai barang komplemen dari beras didasarkan kepada hasil pemilihan model linier berganda yang memberikan model terbaik.

Variabel harga didapatkan dari pembagian antara nilai rupiah yang dikeluarkan untuk mengkonsumsi suatu jenis barang dengan kuantitas barang yang dikonsumsi. Pemilihan variabel terigu didasarkan kepada hasil penelitian Ito et al. (1989) menggunakan variabel harga terigu sebagai barang substitusi dalam menganalisis pola permintaan beras di 14 negara.

Data konsumsi Susenas didapatkan melalui metode wawancara tatap muka antara petugas dengan responden. Responden mengingat apa yang dikonsumsi selama seminggu terakhir. Pengamatan kosong terjadi jika pada rumah tangga tersebut tidak mengkonsumsi beras selama seminggu terakhir pada masa pendataan.

Penelitian ini membagi ke dalam tiga kelompok pendapatan, yaitu kelompok pertama (K1) dengan rentang Rp 300 ribu hingga Rp 999 ribu rupiah; kelompok kedua (K2) dengan rentang Rp 1 juta hingga Rp 1.499 Juta rupiah dan kelompok atas (K3) dengan rentang pendapatan Rp 1.5 juta ke atas. Pengelompokkan ini didasarkan pada justifikasi peneliti dan tim berdasarkan ketersediaan objek yang diteliti.

\section{Metode Analisis dan Pengolahan Data}

Metode analisis yang digunakan dalam penelitian ini adalah analisis deskriptif dan analisis kuantitatif. Analisis deskriptif dilakukan untuk melihat gambaran perilaku dari masingmasing variabel. Analisis kuantitatif yang digunakan adalah model regresi linier berganda untuk melihat faktor-faktor yang memengaruhi permintaan beras rumah tangga dan melihat elastisitas dari sisi pengeluaran, kuantitas dan kualitasnya.

Model regresi linier yang digunakan dalam penelitian ini mengacu pada Desfaryani (2016) dengan persamaan berikut.

$$
\begin{aligned}
Q_{i}= & \alpha_{0}+\alpha_{1} L n Y k a p_{i}+\alpha_{2} \operatorname{LnP} P_{1 i}+\alpha_{3} L n P_{2 i} \\
& +\alpha_{4} L n P_{3 i}+\alpha_{5} H H_{i}+\varepsilon_{i}
\end{aligned}
$$

$$
\begin{aligned}
E_{i}= & \beta_{0}+\beta_{1} \operatorname{LnYkap} i+\beta_{2} \operatorname{LnP} P_{1 i}+\beta_{3} L n P_{2 i} \\
& +\beta_{4} L n P_{3 i}+\beta_{5} H H_{i}+\mu_{i}
\end{aligned}
$$

Keterangan :

$Q_{i} \quad$ : Kuantitas beras yang dikonsumsi rumah tangga ke-i selama sebulan $(\mathrm{kg})$

$E_{i} \quad$ : Pengeluaran beras yang dikonsumsi rumah tangga ke-i selama sebulan (Rp.)

LnYkap $_{i}$ : Logaritma natural dari pendapatan per kapita rumah tangga ke-i dalam sebulan

$\operatorname{LnP}_{l i} \quad$ : Logaritma natural dari harga beras yang dikonsumsi oleh rumah tangga ke-i 


\begin{tabular}{|c|c|}
\hline $\operatorname{Ln} P_{2 i}$ & $\begin{array}{l}\text { Logaritma natural dari harga } \\
\text { terigu yang dikonsumsi oleh } \\
\text { rumah tangga ke-i }\end{array}$ \\
\hline $\operatorname{Ln} P_{3 i}$ & $\begin{array}{l}\text { Logaritma natural dari harga } \\
\text { ayam yang dikonsumsi oleh } \\
\text { rumah tangga ke-i }\end{array}$ \\
\hline$H H_{i}$ & $\begin{array}{l}\text { Jumlah anggota rumah tangga } \\
\text { pada rumah tangga ke-i }\end{array}$ \\
\hline$\varepsilon_{i}$ dan $\mu_{i}$ & $\begin{array}{l}\text { : Residual regresi rumah tangga } \\
\text { ke-i }\end{array}$ \\
\hline$\alpha_{0}$ dan $f$ & Intersep \\
\hline & Rumah tangga ke-i \\
\hline
\end{tabular}

Elastisitas kualitas yang dianalisis dalam penelitian ini mencakup elastisitas yang berkaitan dengan pendapatan dan harga silang. Penghitungan elastisitas yang berkaitan dengan pendapatan dirumuskan sebagai berikut:

$$
\begin{gathered}
\varepsilon_{E Y}=\frac{\partial P}{\partial Y_{k a p}} \frac{Y_{k a p}}{P}+\frac{\partial Q}{\partial Y_{k a p}} \frac{Y_{k a p}}{Q} \\
\varepsilon_{E Y}=\varepsilon_{Q l}+\varepsilon_{Q u}
\end{gathered}
$$

Berdasarkan penghitungan nilai eslastisitas pendapatan, maka beras dapat dikategorikan menjadi tiga kelompok jenis barang, yaitu:
a) $\varepsilon_{E Y}>1$
: Barang mewah
b) $0<\varepsilon_{E Y}<$
: Barang normal
c) $\varepsilon_{E Y}<0$
: Barang inferior

Sementara jika dilihat hubungan suatu barang dengan jenis barang lainnya, barang tersebut dapat dikategorikan menjadi barang substitusi dan barang komplementer. Pindyck dan Rubinfeld 2007 menyatakan bahwa elastisitas harga silang mampu melihat antara kaitan elastisitas harga dengan ada tidaknya suatu barang menggantikan barang yang lain.

Suatu barang dikatakan menjadi barang substitusi apabila kenaikan harga suatu barang dapat memengaruhi kenaikan permintaan suatu barang yang sifatnya sepadan. Suatu barang dikatakan barang komplemen jika kenaikan harga suatu barang direspon dengan penurunan permintaan barang tersebut.

Elastisitas pengeluaran kaitannya dengan harga silang antara beras $\left(P_{1}\right)$ dan terigu $\left(P_{2}\right)$ dituliskan sebagai berikut:

$$
\varepsilon_{E P_{2}}=\frac{\partial P_{1}}{\partial P_{2}} \frac{P_{2}}{P_{1}}+\frac{\partial Q}{\partial P_{2}} \frac{P_{2}}{Q}
$$

Berdasarkan penghitungan nilai eslastisitas harga silang, maka beras dapat dikategorikan menjadi tiga kelompok jenis barang, yaitu:

a) $\varepsilon_{E P_{i}}<0 ;$ maka hubungan antara beras dan terigu adalah komplementer

b) $\varepsilon_{E P_{i}}>0$; maka hubungan antara beras dan terigu merupakan barang substitusi

c) $\varepsilon_{E P_{i}}=0 ;$ maka hubungan antara beras dan terigu tidak terdapat hubungan kegunaan

Jika elastisitas silang bernilai positif, dapat dikatakan hubungan antara beras dengan terigu merupakan hubungan substitusi. Jika elastisitas silang bernilai negatif, dapat dikatakan hubungan antara beras dan terigu merupakan barang yang saling komplemen. Rincian ini dapat diuraikan sebagai berikut:

Secara umum, model matematis elastisitas kualitas seperti yang digunakan oleh Harianto (1994) adalah sebagai berikut:

$$
\varepsilon_{Q l}=\varepsilon_{E}-\varepsilon_{Q}
$$

\section{Keterangan:}

$\begin{array}{lll}\varepsilon_{Q l} & : \text { Elastisitas kualitas } \\ \varepsilon_{E} & : \text { Elastisitas pengeluaran } \\ \varepsilon_{Q} & : \text { Elastisitas kuantitas } \\ \alpha, \beta & : \text { Koefisien regresi } \\ \bar{e} & : \text { Rata-rata pengeluaran beras yang } \\ & \text { dikonsumsi rumah tangga } \\ \bar{q} & : \text { Rata-rata kuantitas beras yang } \\ & \text { dikonsumsi rumah tangga }\end{array}$

Dari persamaan di atas, elastisitas permintaan kualitas beras dapat dilihat sebagai berikut:

a) $\varepsilon_{Q l}<0$; maka adanya kenaikan pendapatan justru akan direspon dengan terjadinya penurunan permintaan kualitas beras oleh masyarakat

b) $\varepsilon_{Q l}>0$; maka kenaikan pendapatan direspon dengan adanya peningkatan permintaan kualitas beras oleh masyarakat

Jika elastisitas kualitas kaitannya dengan harga silang bernilai positif, maka peningkatan pada harga barang lain menyebabkan permintaan 
barang tersebut akan meningkat dari segi kualitas. Dalam hal ini, jika harga terigu naik maka permintaan terhadap beras yang berkualitas lebih baik akan terjadi.

\section{HASIL DAN PEMBAHASAN Gambaran Umum}

Secara garis besar, pola pengeluaran rumah tangga dibedakan menjadi dua kelompok, yaitu pengeluaran untuk konsumsi makanan dan non makanan. Dalam kurun waktu enam tahun terakhir, sepertiga pendapatan penduduk DKI Jakarta digunakan untuk mengkonsumsi makanan. Jika dilihat tren pola pengeluaran rumah tangga, persentase rata-rata pengeluaran konsumsi makanan cenderung mengalami peningkatan. Pada tahun 2011 persentase pengeluaran rata-rata untuk konsumsi makanan sebesar 33.76 persen dan pada tahun 2013 meningkat menjadi sebesar 39.47 persen. Angka persentase ini cenderung terus meningkat hingga mencapai 39.94 persen pada tahun 2017.

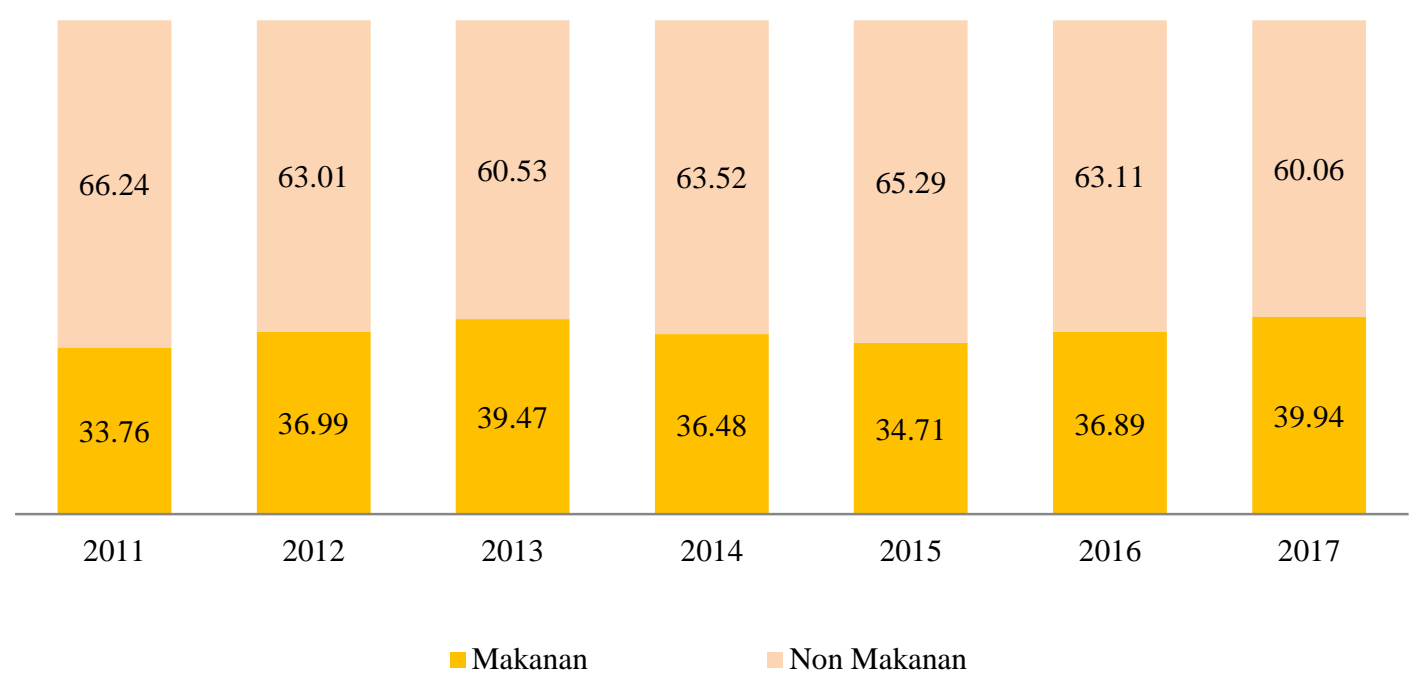

Sumber : BPS, 2011-2017 (diolah)

Gambar 1. Persentase Pengeluaran Penduduk DKI Jakarta, 2011-2017

Persentase konsumsi di atas menggambarkan rata-rata konsumsi berdasarkan kelompok pola konsumsi rata-rata masyarakat di seluruh pendapatan, maka akan didapatkan pola kelompok pendapatan. Akan tetapi jika dilihat konsumsi yang berbeda.

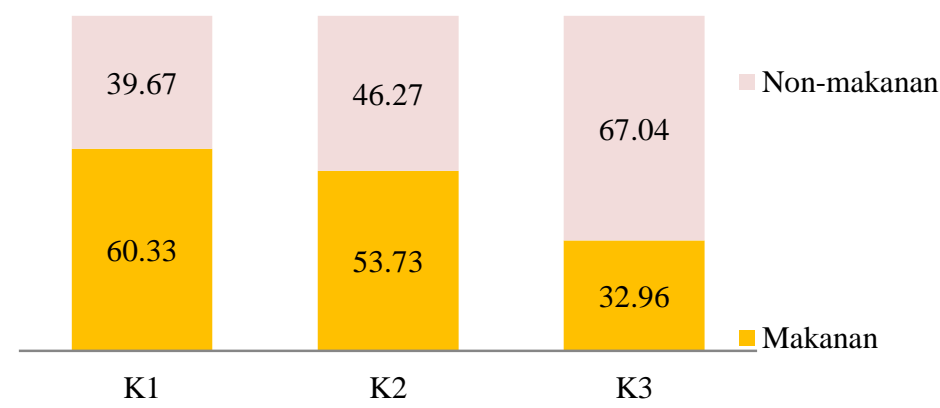

Sumber : BPS, 2017 (diolah)

Gambar 2. Persentase Pengeluaran Penduduk DKI Jakarta menurut Kelompok Pendapatan, 2017

Pada kelompok pendapatan terendah (K1), pendapatan menengah (K2), proporsi dua pertiga pendapatannya dihabiskan untuk pendapatannya dihabiskan separuh untuk mengkonsumsi makanan. Untuk kelompok mengkonsumsi makanan dan separuhnya lagi 
untuk mengkonsumsi non-makanan. Kemudian, untuk kelompok pendapatan tertinggi (K3), pola pengeluarannya berkebalikan dengan kelompok yang berada pada kelompok pendapatan terendah. Kondisi ini sesuai dengan teori Engel yang menyatakan bahwa semakin tinggi tingkat pendapatan seseorang, maka pangsa pengeluaran makanannya semakin rendah.

Untuk konsumsi jenis makanan, hampir sebagian dari penduduk DKI Jakarta menghabiskan pendapatannya untuk mengkonsumsi jenis makanan jadi. Kondisi demikian menunjukkan fenomena penduduk perkotaan yang menyukai makanan yang serba praktis dan instan. Beras menempati posisi keenam dalam urutan konsumsi jenis makanan.

Rokok menempati urutan kedua dalam hal proporsi konsumsi jenis makanan penduduk Jakarta. Persentase pendapatan penduduk DKI Jakarta, rata-rata sebesar 8.64 persen digunakan untuk mengkonsumsi jenis komoditi "berbahaya" ini. Bahkan komoditi ini juga menjadi salah satu komoditi penyumbang inflasi di Jakarta.

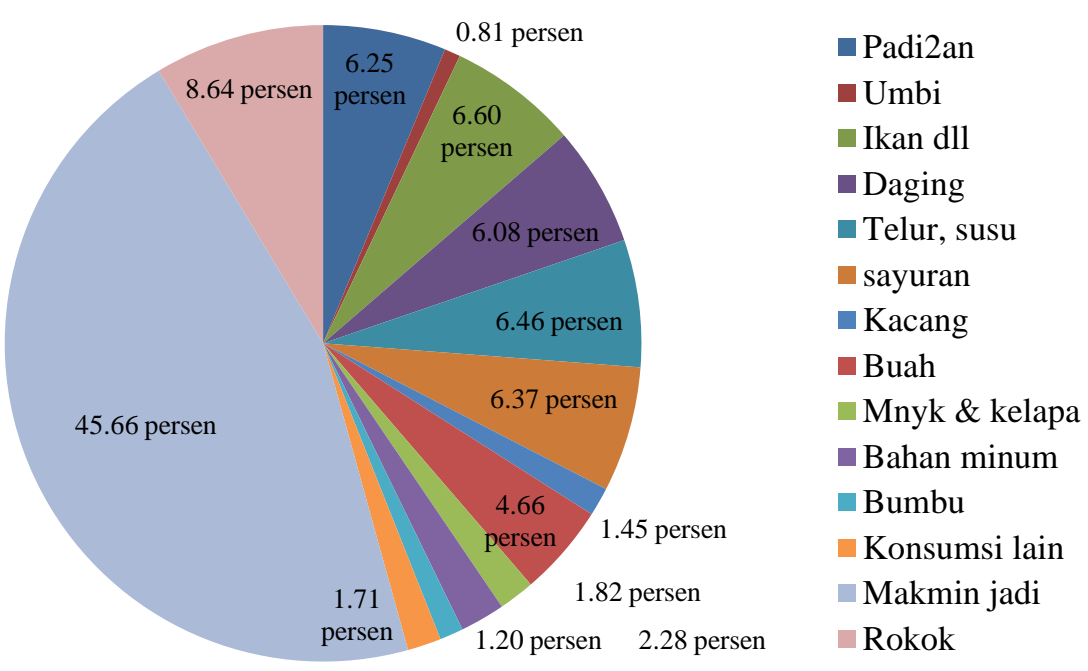

Sumber: BPS, 2017

Gambar 3. Persentase Pengeluaran Penduduk menurut Jenis Makanan, 2017

Beras merupakan salah satu jenis karbohidrat yang paling digemari penduduk Jakarta. Persentase pendapatan yang dihabiskan penduduk Jakarta untuk mengkonsumsi beras adalah sebesar 6.22 persen jika dibandingkan dengan seluruh total makanan yang dikonsumsi. Namun jika dibandingkan terhadap seluruh total pendapatan, proporsi yang digunakan untuk mengkonsumsi beras, nilainya sangatlah kecil yaitu hanya mencapai sebesar 2.47 persen. Fakta ini terkait dengan teori yang menyatakan bahwa semakin kecil bagian pendapatan yang dikeluarkan untuk membeli suatu barang, maka elastisitas barang tersebut akan semakin kecil.

Rata-rata rumah tangga di DKI Jakarta mengkonsumsi beras sebanyak $25.23 \mathrm{~kg}$ dalam sebulan. Jika diamati berdasarkan kelompok pendapatan, banyaknya rata-rata kuantitas beras yang dikonsumsi akan berkurang seiring naiknya tingkat pendapatan. Hal ini sejalan dengan dengan fakta di Jakarta bahwa rata-rata kuantitas beras yang dikonsumsi oleh rumah tangga dengan pendapatan tertinggi sebanyak $23.38 \mathrm{~kg}$. Sementara kelompok rumah tangga pendapatan terendah rata-rata mengkonsumsi beras sebanyak $27.80 \mathrm{~kg}$.

Fenomena ini sesuai dengan teori yang dikemukakan oleh Bennett. Bennett dalam Godfray (2011) menyatakan bahwa penduduk yang semakin sejahtera akan mengubah pola konsumsinya, yang awalnya didominasi oleh simple starchy plant berubah menjadi lebih bervariasi, yaitu mengonsumsi sayuran, buah, produk susu terutama daging.

Bila dilihat berdasarkan harganya, rata-rata penduduk DKI Jakarta mengkonsumsi beras pada harga Rp 8946.71 per kg. Harga beras terendah yang dikonsumsi rumah tangga sebesar Rp 6 000. Sementara harga beras tertinggi yang dikonsumsi rumah tangga ada yang mencapai hingga Rp 70 000. Sehingga range harga beras yang dikonsumsi sangatlah besar. 
Rumah tangga pada kelompok pendapatan terendah mengkonsumsi beras di bawah harga rata-rata yang dikonsumsi oleh penduduk Jakarta. Rata-rata harga beras yang dikonsumsi oleh kelompok ini adalah sebesar Rp 7458.56. Rumah tangga pada kelompok pendapatan tertinggi (K3) mengkonsumsi beras pada rata-rata harga sebesar $\mathrm{Rp} 10$ 611.70. Semakin tinggi kelompok pendapatan, rata-rata harga beras yang dikonsumsi semakin mahal. Hal ini menggambarkan kemampuan tingkat ekonomi dalam memilih kualitas beras yang dikonsumsi.

Besarnya harga yang dikonsumsi akan berpengaruh terhadap pengeluaran rumah tangga untuk mengkonsumsi beras.

Nilai rupiah yang dikeluarkan rumah tangga untuk mengkonsumsi beras selama sebulan adalah sebesar Rp 219 351.98. Namun demikian terdapat rumah tangga yang hanya mengeluarkan Rp 8571.43 untuk mengkonsumsi beras selama sebulan. Angka tersebut berada pada rumah tangga kelompok pendapatan tertinggi. Jika dikaitkan dengan pola perilaku konsumen, rumah tangga tersebut adalah rumah tangga yang lebih banyak mengkonsumsi makanan jadi sehingga mengkonsumsi nasi dalam bentuk makanan jadi seperti nasi rames, dan sebagainya. Fenomena ini menggambarkan perilaku masyarakat perkotaan yang serba praktis.

Uang yang dihabiskan untuk mengkonsumsi beras pada kelompok pendapatan tertinggi adalah sebesar Rp 241 856. Angka ini sangatlah besar jika dibandingkan dengan rata-rata kuantitas beras yang dikonsumsi pada kelompok ini. Dengan demikian dapat diketahui bahwa rumah tangga pada kelompok ini mengkonsumsi beras dengan kualitas yang jauh lebih baik dibandingkan dengan rumah tangga yang berada pada kelompok pendapatan rendah dan menengah.

Berdasarkan pendapatan perkapita yang diproksi melalui pengeluaran perkapita, rata-rata pendapatan perkapita penduduk DKI Jakarta tahun 2017 adalah sebesar Rp 1997 446.38. Pendapatan per kapita penduduk DKI Jakarta terbesar ada di nilai Rp 43205 000. Sementara ada penduduk yang hanya menerima pendapatan per kapita sebesar Rp 312456.67 berada pada kelompok pendapatan terendah.

Tabel 1. Deskripsi variabel yang dianalisis

\begin{tabular}{|c|c|c|c|c|c|}
\hline \multirow{2}{*}{ Variabel } & & \multicolumn{3}{|c|}{ Kelompok pendapatan } & \multirow{2}{*}{$\begin{array}{c}\text { DKI } \\
\text { Jakarta }\end{array}$} \\
\hline & & K1 & $\mathrm{K} 2$ & K3 & \\
\hline \multirow[t]{2}{*}{ Kuantitas beras sebulan $(\mathrm{kg})$} & Mean & 27.80 & 24.89 & 23.38 & 25.23 \\
\hline & $(S t d d e v)$ & $(12.52)$ & $(12.15)$ & $(13.02)$ & $(12.81)$ \\
\hline \multirow[t]{2}{*}{ Pengeluaran beras sebulan (ribu Rp) } & Mean & 206.94 & 195.32 & 241.85 & 219.35 \\
\hline & (Std.dev) & (94.09) & $(96.42)$ & $(144.57)$ & (120.65) \\
\hline \multirow[t]{2}{*}{ Pendapatan per kapita (Ribu Rp) } & Mean & 74066 & 1222.5 & 3285.51 & 1997.45 \\
\hline & (Std.dev) & $(154.46)$ & $(141.95)$ & (2 112.26) & (1 849.97) \\
\hline \multirow{2}{*}{ Harga beras $(\mathrm{Rp} / \mathrm{kg})$} & Mean & 7458.56 & 8015.96 & 10611.70 & 8946.71 \\
\hline & (Std.dev) & $(825.20)$ & (2 501.67) & $(4$ 188.71) & (3 373.49) \\
\hline \multirow{2}{*}{ Jumlah Anggota Rumah Tangga } & Mean & 5.00 & 4.31 & 4.04 & 4.41 \\
\hline & (Std.dev) & (1.79) & $(1.53)$ & $(1.71)$ & $(1.75)$ \\
\hline
\end{tabular}

Sumber: Hasil Olahan 2017

Harga rata-rata terigu adalah sebesar $\mathrm{Rp} 7$ $780.63 / \mathrm{kg}$. Harga terigu terendah yang dikonsumsi oleh rumah tangga adalah $\mathrm{Rp} 4$ 000/kg. Rata-rata harga terigu yang dikonsumsi oleh rumah tangga pada kelompok pendapatan tinggi adalah sebesar Rp 8 976.08/kg.

Daging ayam merupakan komoditi yang paling sering dikonsumsi masyarakat sebagai lauk pauk oleh rumah tangga. Adapun range 
harga untuk komoditi ini adalah sebesar Rp 19 000 harga terendah dan harga tertingginya sebesar Rp 130 000. Rata-rata harga ayam yang dikonsumsi oleh rumah tangga di Jakarta adalah sebesar Rp 29227.78.

Jika dilihat berdasarkan demografinya, satu rumah tangga di Jakarta terdiri dari 4 hingga 5 anggota rumah tangga. Rata-rata jumlah anggota rumah tangga pada kelompok pendapatan terendah berjumlah 5 orang. Jumlah anggota rumah tangga terbanyak di DKI Jakarta adalah sebanyak 15 orang dalam satu rumah tangga.

Tabel 2. Dugaan Paramater yang memengaruhi Kuantitas Permintaan Beras

\begin{tabular}{lcccc}
\hline \multirow{2}{*}{ Variabel } & \multicolumn{3}{c}{ Kelompok Pendapatan } & \multirow{2}{*}{$\begin{array}{c}\text { DKI Jakarta } \\
(\mathrm{n}=1243)\end{array}$} \\
\cline { 2 - 4 } & $\mathrm{K} 1$ & $\mathrm{~K} 2$ & $\mathrm{~K} 3$ & \\
\hline Harga beras & -3.67103 & -10.80135 & -8.84964 & -9.08117 \\
& $(0.3208)$ & $(<.0001)$ & $(<.0001)$ & $(<.0001)$ \\
Harga terigu & 0.73750 & -2.67136 & -1.78847 & -1.43975 \\
& $(0.7071)$ & $(0.2745)$ & $(0.2049)$ & $(0.1559)$ \\
Harga ayam & -3.25846 & -2.67136 & 0.42920 & -1.33771 \\
& $(0.2687)$ & $(0.2745)$ & $(0.7968)$ & $(0.3021)$ \\
Pendapatan per kapita & 4.89931 & -1.12475 & 1.06542 & 2.20598 \\
& $(0.0350)$ & $(0.8106)$ & $(0.2807)$ & $(0.0002)$ \\
Jumlah ART & 4.73317 & 4.49810 & 4.51432 & 4.53456 \\
& $(<.0001)$ & $(<.0001)$ & $(<.0001)$ & $(<.0001)$ \\
\hline F-Statistic & & & & 170.35 \\
$R$-Squared $\left(\mathrm{R}^{2}\right)$ & & & & 0.4078 \\
\hline
\end{tabular}

Sumber: Hasil Olahan 2017

Faktor-faktor yang memengaruhi Permintan Beras di DKI Jakarta

Jumlah sampel yang diobservasi dalam penelitian ini ada sebanyak 1.243 rumah tangga. Rumah tangga yang berada pada kelompok pendapatan rendah (K1) ada sebanyak 364.
Sementara rumah tangga yang berada pada kelompok pendapatan menengah (K2) ada sebanyak 303 dan rumah tangga terbanyak ada pada kelompok pendapatan tertinggi (K3) yaitu sebanyak 576.
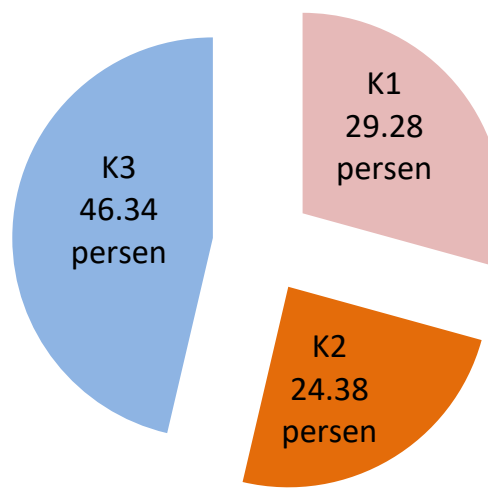

Sumber : Hasil Olahan 2017

Gambar 4. Persentase Sampel menurut Kelompok Pendapatan, 2017 
Secara umum, fungsi permintaan sebuah komoditi dipengaruhi oleh harga komoditi itu sendiri, harga barang lain, pendapatan per kapita, dan jumlah anggota rumah tangga. Pendugaan model permintaan beras dilakukan dengan meregresikan persamaan antara permintaan beras dengan faktor yang memengaruhinya. Permintaan beras dilihat dari sisi kuantitas beras dan pengeluaran untuk mengonsumsi beras.

Peneliti menggunakan uji chow dalam menentukan koefisien penduga yang akan digunakan dalam penghitungan elastisitas. Hasil uji chow menunjukkan bahwa tidak terdapat perbedaan antara koefisien penduga yang digunakan secara umum (Gabungan DKI Jakarta) maupun tiap kelompok pendapatan.

Secara umum di Jakarta, variabel yang memengaruhi permintaan beras adalah harga beras, pendapatan per kapita dan jumlah anggota rumah tangga. Nilai $R$-squared sebesar 0.4078 yang menunjukkan bahwa 40.78 persen model mampu dijelaskan oleh variabel dalam model.

Untuk kelompok pendapatan terendah, variabel yang signifikan memengaruhi kuantitas permintaan beras adalah pendapatan per kapita dan jumlah anggota rumah tangga. Jika pendapatan per kapita meningkat sebanyak 1 persen maka kuantitas permintaan beras akan meningkat sebanyak $0.0049 \mathrm{~kg}$. Kenaikan pendapatan pada kelompok pendapatan terendah meningkatkan permintaan beras dari sisi kuantitas. Fenomena ini sejalan dengan hukum Bennet.

Sementara jika jumlah anggota rumah tangga bertambah 1 orang, maka jumlah beras yang diminta akan meningkat sebesar $4.7 \mathrm{~kg}$ cateris paribus. Semakin banyak jumlah anggota rumah tangga maka permintaan beras rumah tangga akan semakin besar. Hasil tersebut sesuai dengan penelitian Hapsari et al. (2015) dan Herdiansyah (2016).

Pada kelompok pendapatan menengah, variabel yang memengaruhi permintaan beras adalah harga beras dan jumlah anggota rumah tangga. Harga beras memiliki hubungan yang berlawanan arah dengan kuantitas permintaan beras. Hubungan yang berlawanan arah antara beras dengan permintaan sejalan dengan hasil penelitian Sugiyanto (2006). Besarnya perubahan permintaan kuantitas beras atas kenaikan harga di ketiga kelompok pendapatan berada pada kelompok pendapatan menengah. Apabila terjadi kenaikan 1 persen harga beras, maka kuantitas beras menurun sebesar $0.11 \mathrm{~kg}$.

Variabel yang berpengaruh terhadap permintaan beras pada kelompok pendapatan tertinggi adalah harga beras dan jumlah anggota rumah tangga. Kenaikan 1 persen harga akan direspon dengan penurunan permintaan kuantitas beras sebanyak $0.088 \mathrm{~kg}$. Sementara bertambahnya 1 orang anggota rumah tangga akan meningkatkan permintaan beras sebanyak $4.5 \mathrm{~kg}$.

Hasil regresi permintaan beras dari sisi nilai pengeluarannya memberikan hasil yang variatif. Secara umum di DKI Jakarta, harga beras, pendapatan per kapita dan jumlah anggota rumah tangga memengaruhi secara positif terhadap permintaan beras. Semakin mahal harga beras yang dikonsumsi maka akan semakin besar uang yang dikeluarkan untuk mengonsumsi beras. Semakin besar pendapatan per kapita yang diterima, maka orang tersebut akan memilih beras dengan kualitas yang lebih baik. Sementara beras dengan kualitas yang baik dicerminkan oleh harga yang lebih mahal. Semakin banyak individu yang tinggal dalam suatu rumah tangga maka uang yang dikeluarkan untuk mengkonsumsi beras juga akan semakin besar.

Hasil estimasi pada Tabel 3 menunjukkan bahwa nilai $R$-Squared sebesar 0.427 artinya bahwa 42.70 persen model mampu dijelaskan oleh variabel yang digunakan di dalam model. Sementara sisanya dijelaskan oleh variasi variabel di luar model. Setiap kenaikan 1 persen pendapatan per kapita rumah tangga di DKI Jakarta akan meningkatkan permintaan beras yang dikonsumsi rumah tangga sebesar $\mathrm{Rp}$ 271.35, ceteris paribus. Semakin tinggi tingkat pendapatan, maka tingkat utilitas terhadap suatu barang juga semakin meningkat. Hasil ini sesuai dengan Erwidodo et al. (1997) yang menyatakan bahwa naiknya tingkat pendapatan mendorong rumah tangga untuk mengkonsumsi jenis beras dengan kualitas yang lebih baik yang dicerminkan dengan rasa yang lebih enak.

Apabila terjadi kenaikan 1 persen harga beras maka pengeluaran beras rumah tangga akan naik sebesar $\mathrm{Rp} 1$ 058.19, ceteris paribus. Peningkatan jumlah anggota rumah tangga 
sebanyak 1 jumlah jiwa akan berpengaruh pada peningkatan konsumsi beras sebesar Rp 39 940, ceteris paribus. Hasil tersebut sesuai dengan penelitian Heriyanto (2016) dan Masitoh (2018).

Variabel yang signifikan memengaruhi permintaan beras pada kelompok pendapatan terendah adalah harga beras, pendapatan per kapita dan jumlah anggota rumah tangga. Seluruh variabel memiliki hubungan yang searah dengan permintaan beras dari sisi pengeluaran. Besaran koefisien variabel harga di kelompok pendapatan terendah ini merupakan yang paling besar di antara dua kelompok pendapatan lainnya, nilainya sebesar 130.99 (ribu). Setiap kenaikan 1 persen harga beras, maka pengeluaran rumah tangga untuk mengkonsumsi beras naik sebesar Rp 13 099, cateris paribus.

Tabel 3. Dugaan Paramater yang memengaruh Permintaan Beras (Pengeluaran)

\begin{tabular}{lrrrr}
\hline \multirow{2}{*}{ Variabel } & \multicolumn{3}{c}{ Kelompok Pendapatan } & DKI Jakarta \\
\cline { 2 - 4 } & 1 & 2 & 3 & $\begin{array}{r}(\mathrm{n}=1243) \\
(\mathrm{n}=364)\end{array}$ \\
\cline { 2 - 4 }$(\mathrm{n}=303)$ & $(\mathrm{n}=576)$ & \\
\hline Harga beras (Ribu) & 130.99096 & 66.93961 & 117.14147 & 105.81864 \\
& $(<.0001)$ & $(0.0016)$ & $(<.0001)$ & $(<.0001)$ \\
Harga terigu (Ribu) & 9.31209 & -21.55892 & -12.79402 & -7.80225 \\
& $(0.5418)$ & $(0.2645)$ & $(0.3906)$ & $(0.4055)$ \\
Harga ayam (Ribu) & -26.91273 & -31.46101 & 2.11357 & -11.85852 \\
& $(0.2401)$ & $(0.1988)$ & $(0.9045)$ & $(0.3226)$ \\
Pendapatan per kapita (Ribu) & 42.59010 & -4.02923 & 14.61122 & 27.13541 \\
& $(0.0185)$ & $(0.9135)$ & $(0.1617)$ & $(<.0001)$ \\
Jumlah ART (Ribu) & 34.38188 & 32.94795 & 47.51883 & 39.93975 \\
& $(<.0001)$ & $(<.0001)$ & $(<.0001)$ & $(<.0001)$ \\
\hline F-Statistic & & & & 184.34 \\
R-Squared (R $\left.{ }^{2}\right)$ & & & & 0.4270 \\
\hline
\end{tabular}

Sumber: Hasil olahan 2017

Pendapatan per kapita pada kelompok pendapatan terendah signifikan dan berhubungan positif terhadap konsumsi beras dari sisi nilai rupiah yang dikeluarkan. Pengaruh pendapatan per kapita yang signifikan ini hanya terjadi pada kelompok pendapatan terendah, sementara pada kelompok pendapatan menengah dan kelompok pendapatan tertinggi tidak berpengaruh.

Baik pada kelompok pendapatan terendah, menengah dan tertinggi, variabel jumlah anggota rumah tangga berpengaruh positif dan secara signifikan berpengaruh terhadap permintaan beras dari sisi pengeluarannya. Hanya saja besaran pengaruhnya terjadi pada kelompok pendapatan tertinggi. Sementara pada kelompok pendapatan terendah, nilainya sebesar 34.38 yang artinya bahwa apabila terjadi penambahan 1 orang anggota rumah tangga, maka uang yang dikeluarkan rumah tangga untuk mengkonsumsi beras naik sebesar Rp 34382.

\section{Elastisitas Kuantitas dan Kualitas Beras}

Elastisitas menunjukkan respon perubahan permintaan. Respon perubahan permintaan terjadi bisa disebabkan oleh akibat perubahan harga maupun pendapatan. Elastisitas pendapatan terhadap pengeluaran dan kuantitas beras bersifat inelastis karena nilai elastisitasnya kurang dari 1. Angka ini sesuai dengan hukum Engel yang memberikan konsekuensi bahwa elastisitas pendapatan dari permintaan untuk makanan ratarata akan kurang dari satu. Kemudian elastisitasnya akan relatif besar bagi konsumen berpenghasilan rendah dan menurun ke tingkat yang sangat kecil untuk konsumen berpenghasilan tinggi (Miranti 2017). 
Nilai elastisitas pengeluaran relatif lebih besar jika dibandingkan dengan elastisitas kuantitas. Sesuai dengan pernyataan Gale dan Huang (2007) bahwa kondisi ini mencerminkan efek kualitas dimana nilai rupiah yang dikeluarkan untuk mengkonsumsi beras lebih cepat dibandingkan kuantitas komoditi yang dikonsumsi ketika pendapatan rumah tangga tumbuh.

Tabel 4. Elastisitas pengeluaran, kuantitas dan kualitas beras di DKI Jakarta Tahun 2017

\begin{tabular}{ccccc}
\hline \multirow{2}{*}{ Elastisitas } & \multicolumn{3}{c}{ Kelompok pendapatan } & \multirow{2}{*}{ DKI Jakarta } \\
\cline { 2 - 4 } & $\mathrm{K} 1$ & $\mathrm{~K} 2$ & $\mathrm{~K} 3$ & \\
\hline Pengeluaran & 0.12872 & 0.13366 & 0.11099 & 0.11776 \\
Kuantitas & 0.07845 & 0.08745 & 0.09581 & 0.08634 \\
Kualitas & 0.05027 & 0.04622 & 0.00152 & 0.03142 \\
\hline
\end{tabular}

Sumber: Hasil Olahan 2017

Elastisitas pengeluaran menunjukkan respon banyaknya uang yang dikeluarkan untuk mengkonsumsi beras apabila pendapatan meningkat. Elastisitas pengeluaran di DKI Jakarta untuk beras sebesar 0.11776. Apabila terjadi kenaikan pendapatan sebesar 10 persen, maka pengeluaran penduduk Jakarta untuk mengkonsumsi beras hanya naik sebesar 1.18 persen.

Elastisitas pengeluaran terbesar justru ada pada kelompok pendapatan menengah yaitu sebesar 0.13366. Elastisitas pengeluaran beras pada kelompok pendapatan tertinggi sangatlah kecil yaitu sebesar 0.11. Fenomena ini sesuai dengan hasil penelitian Kahar (2010), semakin tinggi pendapatan maka elastisitas pengeluaran makanan pokok semakin rendah. Adanya kenaikan pendapatan akan dialokasikan untuk mengkonsumsi jenis komoditi lainnya.

Selain elastisitas pengeluaran, untuk melihat perubahan respon permintaan beras dalam hal ini peneliti juga ingin melihat elastisitas kuantitas. Elastisitas kuantitas mencerminkan respon perubahan banyaknya permintaan beras yang dikonsumsi apabila terjadi kenaikan pendapatan.

Jika dilihat nilainya, elastisitas kuantitas kelompok pendapatan terendah untuk komoditi beras sebesar 0.07845. Hal ini menujukkan apabila pendapatan per kapita meningkat sebesar 10 persen, maka permintaan beras penduduk DKI Jakarta akan meningkat sebesar 0.78 persen. Tabel 4 menunjukkan bahwa semakin tinggi kelompok pendapatan, maka respon perubahan permintaan beras semakin besar walaupun perbedaanya tidak terlalu besar.

Baik berdasarkan kelompok pendapatan maupun secara umum, elastisitas kualitas permintaan beras bertanda positif. Artinya, semakin tinggi tingkat pendapatan maka permintaan terhadap beras dengan kualitas yang lebih baik akan semakin meningkat. Jika dilihat menurut kelompok pendapatan, semakin tinggi kelompok pendapatan maka elastisitas kualitas beras semakin rendah.

Hal ini menunjukkan bahwa semakin tinggi tingkat pendapatan maka sudah tidak terlalu sensitif terhadap perubahan kualitas beras yang dikonsumsi apabila terjadi kenaikan pendapatan karena pada dasarnya beras yang mereka konsumsi memang sudah berkualitas. Kemungkinan lainnya adalah beras bukan lagi komoditi konsumsi primer pada kelompok pendapatan tinggi, komoditi beras tergantikan komoditi jenis makanan lain yang tinggi nutrisi dan rendah karbohidrat. Secara umum, elastisitas kualitas beras di DKI Jakarta sangatlah rendah, yakni sebesar 0.03142. Apabila terjadi kenaikan 10 persen pendapatan per kapita, maka permintaan beras dengan kualitas yang baik hanya akan meningkat sebesar 0.31 persen.

Perubahan permintaan kualitas beras dicerminkan dari perubahan permintaan penduduk terhadap beras pada tingkat harga yang berbeda. Beras dengan harga Rp 13000 dianggap memiliki kualitas yang lebih baik jika dibandingkan dengan beras dengan harga Rp 10 000. Dengan begitu, tingkat harga yang lebih 
tinggi menunjukkan kualitas beras yang lebih baik.

Selain melihat elastisitas dari sisi pendapatan, elastisitas juga bisa dilihat dari harga silangnya.
Dalam penelitian ini, harga silang yang berkaitan dengan beras adalah harga terigu dan daging ayam. Berikut merupakan tabel yang menunjukkan elastisitas harga silang.

Tabel 5. Elastisitas Harga Silang antara Beras, Terigu dan Daging Ayam, 2017

\begin{tabular}{llccr}
\hline Elastisitas & \multicolumn{3}{c}{ Kelompok pendapatan } & \multirow{2}{*}{ DKI Jakarta } \\
\cline { 2 - 3 } & $\mathrm{K} 1$ & $\mathrm{~K} 2$ & $\mathrm{~K} 3$ \\
\hline Beras terhadap terigu \\
$\quad$ Pengeluaran & -0.03701 & -0.03843 & -0.03192 & -0.03385 \\
$\quad$ Kuantitas & -0.05076 & -0.05658 & -0.06199 & -0.05587 \\
Beras terhadap daging ayam & & & & \\
$\quad$ Pengeluaran & -0.0563 & -0.0584 & -0.0485 & -0.0523 \\
$\quad$ Kuantitas & -0.0476 & -0.0530 & -0.0581 & -0.0514
\end{tabular}

Sumber: Hasil Olahan 2017

Pada bagian ini, elastisitas yang ingin dilihat dari sisi pengeluaran dan kuantitas tidak melibatkan kualitas. Secara umum elastisitas harga silang antara beras dan terigu memiliki tanda yang negatif. Artinya kenaikan harga terigu akan menyebabkan menurunnya permintaan beras. Dengan demikian, hubungan beras dengan terigu di Jakarta maupun pada tiap kelompok pendapatan merupakan hubungan yang saling komplemen. Hal ini menunjukkan bahwa terigu tidak lagi menjadi barang substitusi beras di DKI Jakarta. Terigu bisa dijadikan sebagai bahan pelengkap dalam mengkonsumsi beras, contohnya adalah gorengan. Gorengan membutuhkan terigu dalam pengolahannya. Di Jakarta sudah lazim makan nasi dengan lauk tempe goreng tepung ataupun makan nasi uduk bersama bakwan.

Elastisitas silang antara beras dan ayam bertanda negatif. Fenomena ini menunjukkan bahwa secara umum hubungan antara beras dan ayam memiliki hubungan yang komplemen. Kenaikan harga ayam akan menyebabkan menurunnya permintaan beras rumah tangga, begitu juga sebaliknya. Sudah diketahui secara umum bahwa ayam sering dikonsumsi menjadi lauk dalam mengkonsumsi nasi.

\section{SIMPULAN DAN SARAN Simpulan}

Secara umum, semakin tinggi tingkat pendapatan maka rata-rata kuantitas beras yang dikonsumsi akan semakin menurun. Namun sebaliknya, tingginya tingkat pendapatan akan mendorong rumah tangga tersebut untuk memilih beras dengan kualitas yang lebih baik yang tercermin dari harga yang semakin mahal. Sehingga pengeluaran rumah tangga untuk mengkonsumsi beras juga semakin besar.

Kelompok pendapatan yang semakin tinggi akan semakin rendah sensitivitasnya terhadap perubahan harga beras dan pendapatan. Hal ini disebabkan karena penduduk yang berada pada kelompok pendapatan tinggi sudah mengkonsumsi beras dengan kualitas yang baik dan bisa jadi juga sudah mulai mendiversifikasi jenis pangannya yang sudah tidak terfokus kepada beras.

\section{Saran}

Hasil penelitian merekomendasikan bahwa pemerintah harus sudah memperhatikan produksi beras yang tidak hanya dari sisi kuantitas, akan tetapi juga dari sisi kualitas. Beras yang berkualitas dapat terwujud dengan memerhatikan kualitas benih yang baik saat penanaman dan memperhatikan perawatan pascapanen mulai dari perontokan, pengangkutan, pengeringan gudang yang layak untuk penyimpanan dan penggilingan 
yang baik sampai beras siap dipasarkan atau dikonsumsi. Kualitas beras yang baik akan berpengaruh terhadap performa penduduk yang pada akhirnya akan meningkatkan produktivitas dan daya saing yang tinggi.

\section{DAFTAR PUSTAKA}

Deaton A, Muellbauer J. 1980. Economics and consumer behavior. Newyork. Cambridge University Press.

Deaton, A. 1988. Quality, Quantity, and Spatial Variation of Price. American Economic Review, Vol 78 (3): 418-430.

Desfaryani R. 2015. Permintaan kuantitas dan kualitas buah-buahan rumah tangga di Provinsi Lampung [tesis]. Bogor: Institut Pertanian Bogor.

Dornbusch R, Fischer S, Startz R. 2004. Makroekonomi. PT Media Global Edukasi. Terjemahan dari Macroeconomics.

Erwidodo, Ariani M, Purwoto A. 1997. Perkembangan konsumsi dan proyeksi permintaan beras di Indonesia. doi:10.21082/jae.v16n1-2.1997.42-60.

Fayaz M, Jan AU, Jan D. 2014. Quality elasticity of vegetable consumption in Pakistan: a comparison of urban and rural household. Sarhad Journal of Agriculture. 30 (4):451.

Fitria P. 2012. Analisis pola konsumsi pangan masyarakat di Provinsi Maluku [tesis]. Jakarta: Universitas Indonesia.

Gale F, Huang K. 2007. Demand For Food Quantity And Quality In China. Economic Research Report Number 32. Economic Research Service. United States Department Of Agriculture.

Hapsari EP, Sutrisno J, Ani SW. 2015. Analisis faktor-faktor yang mempengaruhi permintaan beras di Kabupaten Wonogiri. Agrista. 3(3):360-370.

Harianto. 1994. An Empirical Analysis of Food Demand in Indonesia: A Cross-sectional Study [Disertasi]. Bundoora. La Trobe University.

Herdiansyah, A. 2016. Analisis permintaan beras di kabupaten Lumajang [skripsi]. Jember: Universitas Jember.

Heriyanto. 2016. Perilaku konsumsi pangan sumber karbohidrat rumah tangga petani kelapa sawit di Kecamatan Kandis
Kabupaten Siak. Jurnal Ilmiah Pertanian. 13 (1):22-30.

Isvilanonda S, Kongrith W. 2008. Thai household's rice consumption and its demand elasticity. ASEAN Economic Bulletin. 25(3).doi:10.1353/ase.0.0028.

Kahar M. 2010. Analisis pola konsumsi daerah perkotaan dan perdesaan serta keterkaitannya dengan karakteristik Sosial Ekonomi di Provinsi Banten [tesis].. Bogor: Institut Pertanian Bogor.

Kementerian Perdagangan. 2013. Laporan Akhir Analisis Dinamika Konsumsi Pangan Masyarakat Indonesia. Jakarta: Kemendag. Kuntjoro, SU. 1982. Elastisitas pendapatan dari permintaan beras penduduk Indonesia. IAARD E-Journal [internet]. [diunduh $2018 \quad$ Okt 07]; $\quad$ Tersedia pada:http//ejurnal.litbang.pertanian.go.id/in dex.php/jae/article/view/5263.

Masitoh, H. 2018. Analisis Faktor-faktor yang Mempengaruhi Konsumsi Rumah Tangga Beras dan Non Beras. USU Jurnal [internet]; [diunduh 2019 Okt 31]; Tersedia

pada:http//jurnal.usu.ac.id/index.php/ceress /article/download.

Miranti A. 2017. Pengaruh pendapatan dan harga pangan terhadap tingkat diversifikasi pangan rumah tangga di Provinsi Jawa Barat [tesis]. Bogor: Institut Pertanian Bogor.

Nicholson W. 2002. Mikroekonomi Intermediate dan aplikasinya. Edisi ke-8. Jakarta: Erlangga.

Ogundari, K. 2012. Demand for Food Quantity Versus Quality in Beef, Chicken, and Fish Consumption in Nigeria. Revista De Economia E Agronegocio. 10(1): 29-50.

Sugiyanto, C. 2006. Permintaan Beras di Indonesia:Revisited. Jurnal Ekonomi dan Bisnis Indonesia. 21(2): 138-155.

Wahyuni D, Purnastuti L, Mustofa. 2016. Analisis elastisitas tiga bahan pangan sumber protein hewani di Indonesia. Jurnal Economia.12(1):43-53.

Wibowo IP. 2017. Analisis tipe perilaku konsumen beras bermerk di Kabupaten Sukoharjo [tesis]. Surakarta: Universitas Sebelas Maret. 
Yu X. Abler D. 2009. The demand for food duality in Rular China. Jurnal Ekonomi Pembangunan 13(1):51-60 